\title{
Evidence of Some Major Structures Underlying the Douala Sedimentary Sub-Basin: West African Coastal Basin
}

\author{
Eric N. Ndikum ${ }^{1,2 *}$, Charles T. Tabod ${ }^{1,3}$, F. Koumetio ${ }^{4}$, Noutchogwe C. Tatchum ${ }^{5}$, \\ Kenfack J. Victor ${ }^{6}$ \\ ${ }^{1}$ Department of Physics, University of Yaoundé I, Yaoundé, Cameroon \\ ${ }^{2}$ Department of Fundamental Sciences, Higher Technical Teacher Training College (HTTTC) Bambili, The University of \\ Bamenda, Bamenda, Cameroon \\ ${ }^{3}$ Department of Physics, Faculty of Science, The University of Bamenda, Bamenda, Cameroon \\ ${ }^{4}$ Department of Physics, Faculty of Science, University of Dschang, Dschang, Cameroon \\ ${ }^{5}$ Department of Physics, HTTC Bambili, The University of Bamenda, Bamenda, Cameroon \\ ${ }^{6}$ Department of Earth Science, Faculty of Science, University of Dschang, Dschang, Cameroon \\ Email: ^ndikumeric@yahoo.com
}

How to cite this paper: Ndikum, E.N., Tabod, C.T., Koumetio, F., Tatchum, N.C. and Victor, K.J. (2017) Evidence of Some Major Structures Underlying the Douala Sedimentary Sub-Basin: West African Coastal Basin. Journal of Geoscience and Environment Protection, 5, 161-172.

https://doi.org/10.4236/gep.2017.57013

Received: May 19, 2017

Accepted: July 18, 2017

Published: July 21, 2017

Copyright (c) 2017 by authors and Scientific Research Publishing Inc. This work is licensed under the Creative Commons Attribution International License (CC BY 4.0).

http://creativecommons.org/licenses/by/4.0/

cc) (i) Open Access

\begin{abstract}
Gravity data have been processed in the Douala sedimentary sub-basin in a section consisting of a set of 116 gravity data points located between latitudes $3^{\circ} 03^{\prime} \mathrm{N}$ and $4^{\circ} 06^{\prime} \mathrm{N}$ and longitudes $9^{\circ} 00^{\prime} \mathrm{E}$ and $10^{\circ} 00^{\prime} \mathrm{E}$. The established Bouguer anomaly fields and the Residual anomaly fields, extracted by upward continuation at an optimum height of $30 \mathrm{~km}$, were both characterized by considerably high positive anomalies. These anomalies showed many ring-like positive gravity anomaly contour lines in the study region. Gravity gradients were analysed using the multi-scale horizontal derivative of the vertical derivative (MSHDVD) method, and this excluded the existence of fault lines across this region. Amplitude spectrum was used to estimate the potential field source at a depth of about $4.8 \mathrm{~km}$. The ideal body theory capable of handling sparse data contaminated with noise was applied along a $50.2 \mathrm{~km}$ WWS-EEN profile to determine a density contrast of $0.266 \mathrm{~g} / \mathrm{cm}^{3}$. Using these results as constraints, 2.5 $\mathrm{D}$ modelling carried out along this profile presented two major blocks with density contrast of $0.266 \mathrm{~g} / \mathrm{cm}^{3}$. The first block is probably an intrusive igneous body with a density of about $2.77 \mathrm{~g} / \mathrm{cm}^{3}$, having an average thickness of about $26 \mathrm{~km}$ with its top and base lying at depths of about $4.25 \mathrm{~km}$ and 30.25 $\mathrm{km}$ respectively. The second block is likely a pillar of igneous material, located at a depth of about $10.77 \mathrm{~km}$ with a density of about $2.77 \mathrm{~g} / \mathrm{cm}^{3}$ whose base goes deep down beyond the crust-mantle boundary. These results support previous findings that there are similarities between the Douala sedimentary
\end{abstract}


sub-basin and the coastal sedimentary basin of Mauritania-Senegal and thus foster the suggestions of a more extensive movement that would have affected the whole of the West African coast.

\section{Keywords}

Douala Sedimentary Sub-Basin, Bouguer Anomaly, Residual Field, 2.5D Model, Igneous Block

\section{Introduction}

The region under study goes from longitudes $9^{\circ} 00^{\prime} \mathrm{E}$ to $10^{\circ} 00^{\prime} \mathrm{E}$ and latitudes $3^{\circ} 03^{\prime} \mathrm{N}$ to $4^{\circ} 06^{\prime} \mathrm{N}$ (Figure 1 ). It constitutes the Douala sedimentary sub-basin

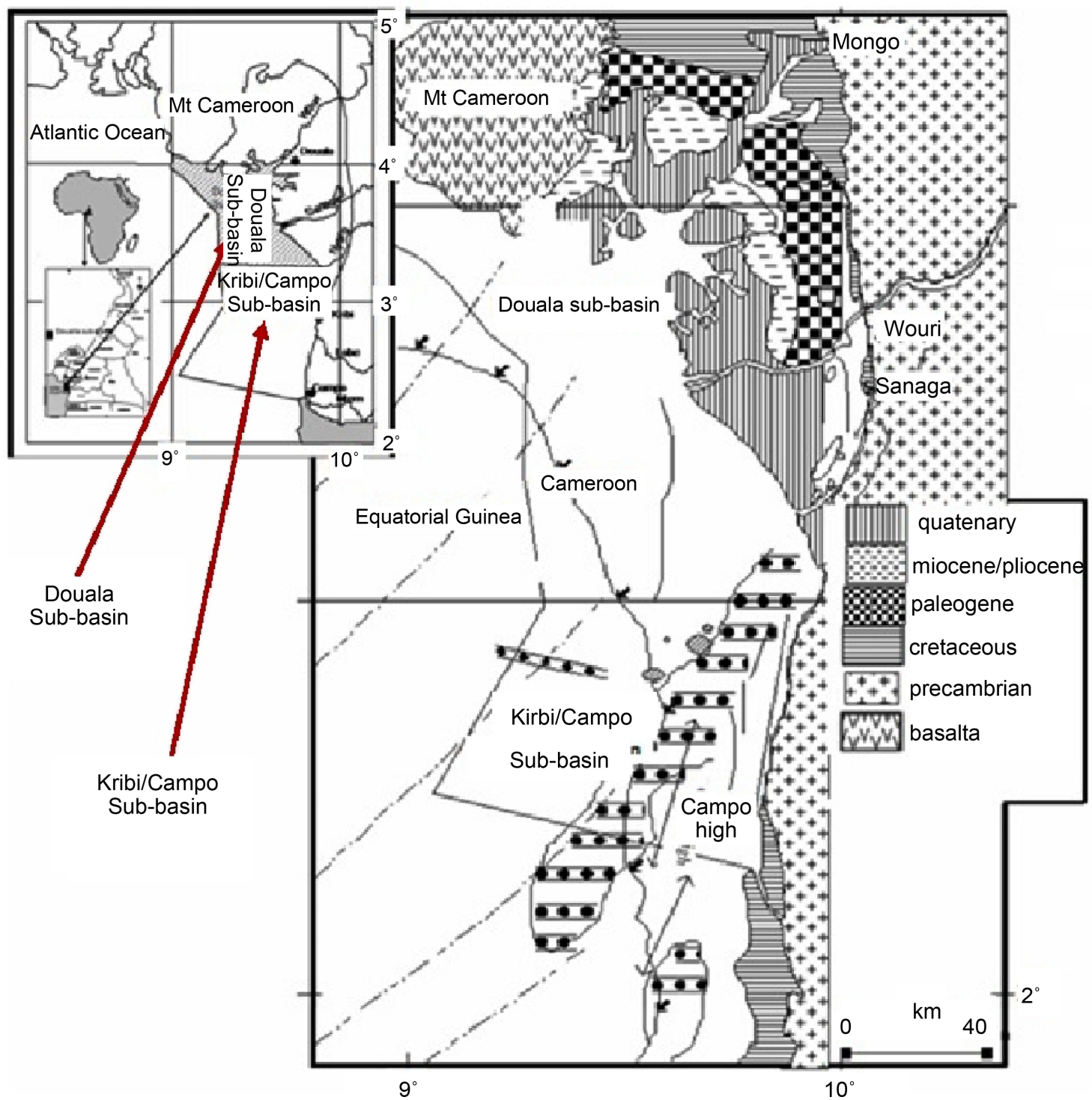

Figure 1. Location map of Cameroon (West Africa) and outlines of the Douala and Kribi/Campo sedimentary sub-basins. (Modified from SNH (1999) in: [9]). 
which together with the Kribi-Campo sub-basin makes up the Douala/KribiCampo sedimentary basin, one of the major basins of the Cameroon Atlantic basin. The Douala/Kribi-Campo basin is also part of the broader Aptian salt basin of Equatorial West Africa [1]. To the North of the Douala sub-basin is the Cameroon Volcanic Line (CVL) [2] [3] [4] while the Kribi-Campo sub-basin is located to the south. The Douala/Kribi-Campo basin has been shown to have the shape of a half-graben [5]. Some other studies have identified a zone with isogals oriented NNW-SSE to N-S, zones of positive anomalies reaching maximums of 30 mgal which are ring-like and present E-W gradient of approximately 2.2 $\mathrm{mgal} / \mathrm{km}$ [6] [7]; which could be as a result of an uplift of dense material that forms a dome with small material [7]. In another study along Bouguer gravity profiles [7], two major structures were located: one being a half-dome of mantle material and the other a pillar of high density rocks. The work of Ndikum et al. [8] along a NW-SE profile brought to light an anomalous body below this basin which was shown to be probably an intrusive igneous block with density $2.77 \mathrm{~g} / \mathrm{cm}^{3}$.

In this study, 2.5D gravity modelling will be carried out along a WWS-EEN oriented profile with the aim of obtaining more information on the existing structures found in the sub-surface region of the Douala sub-basin.

\section{Geological \& Tectonic Settings}

The Douala sub-basin lies between latitudes $3^{\circ} 03^{\prime} \mathrm{N}$ and $4^{\circ} 06^{\prime} \mathrm{N}$ and longitudes $9^{\circ} 00^{\prime} \mathrm{E}$ and $10^{\circ} 00^{\prime} \mathrm{E}$, covering a total surface area of $12,805 \mathrm{~km}^{2}$ (Figure 1). It has a crescent shape which starts from the south-eastern border of Mount Cameroon with the onshore part of about $70 \mathrm{~km}$ wide (in the N20E direction) and extends throughout the Atlantic coast showing a gradual decrease in width of the onshore part towards the South up to Londji (located to the North of Kribi). The eastern limit of the sub-basin is the late Proterozoic Pan-African belt. The gradual North-South opening of the South Atlantic is linked to the formation of the Douala sub-basin, which resulted in the diachronism of deposits from South to North and a temporal and spatial variation of sedimentary environments along the West African coast [10]. According to Reyre [11], Hoffman [12] \& Njike [5], an explanation to the half-graben form of the Douala sub-basin is in its creation which could have been controlled by an E-W distension that could have provoked the complete rupture between the African \& South American continents giving rise to the opening of the South Atlantic.

The basic stratigraphy of the Douala sub-basin is interpreted to comprise of pre-rift, rift, transition and drift megasequences related to the tectonic evolution over African cratonic basement and associated Atlantic margin. On the other hand, the regional stratigraphy and tectonics can be summarized in four main phases of evolution related to pre, syn and post-rift separation of Africa from South America [1]. Its lithostratigraphy consists of seven major Formations related to its geodynamic and sedimentary evolution [13] [14] [15] which include: 1) the Mundeck Formation (Aptian-Cenomanian) which represents the syn-rift period; 2) the Logbadjeck Formation (Cenomanian-Campanian), discordant 
onto the Mundeck Formation; 3) the Logbaba Formation (Maastrichtian); 4) the N'kapa Formation (Paleocene-Eocene); 5) the Souellaba Formation (Oligocene) lying unconformably on N'kapa deposits; 6) the Matanda Formation (Miocene); and 7) the Wouri Formation (Plio-Pleistocene); all these last six formations make up the postrift sequence [16].

The Douala sub-basin contains a more continuous stratigraphic section, and is larger than the Rio del Rey basin. Shallow marine limestones, sandstones and shales overlay late Cretaceous, Palaeogene and Neogene ages Continental basal Cretaceous sands. At the western margin of the basin these formations are overlain by basaltic lavas from the Cameroon volcanic centre. When traced offshore, the sedimentary formations thicken markedly, with evidence for over $7 \mathrm{~km}$ of subsidence since the middle of the Cretaceous Period. There are more sands and fewer shales than in the Rio del Rey basin, and growth in faulting and diapirism due to overpressured shales are largely absent [17].

From its tectonic platform, the Douala sub-basin was given rise to by the Cretaceous break-up of Gondwana and the separation of Africa from South America. Though the initial rifting phase may have started during very Early Cretaceous time (Berriasian-Hauterivian), the principal rifting episode in these areas occurred from late Barremian-Aptian time. It is believed that the initial formation of oceanic crust began during the late Aptian-late Albian interval, as the continents separated. During the passive "drift" phase of the continental margin evolution, several additional tectonic events occurred at $84 \mathrm{Ma}$ (Santonian), $65 \mathrm{Ma}$ (Cretaceous/Tertiary boundary) and $37 \mathrm{Ma}$ (late Eocene). The final uplift event relates to the growth of the Cameroon Volcanic Line (CVL) and effectively lasts from $37 \mathrm{Ma}$ through to present day on the northwest margin of the basin [10].

\section{Data Processing \& Interpretation}

\subsection{Residual Field}

Gravity data constituted of 116 data points with positions located between latitudes $3^{\circ} 03^{\prime} \mathrm{N}$ and $4^{\circ} 06^{\prime} \mathrm{N}$ and longitudes $9^{\circ} 00^{\prime} \mathrm{E}$ and $10^{\circ} 00^{\prime} \mathrm{E}$ were used for this study. Upon interpolation on a 100 by 100 square grid with spacings of 0.0285 in longitude axis and 0.0250 in latitude axis, a Bouguer anomaly map having contour interval of $12 \mathrm{mGal}$ was generated (Figure 2). Very high positive anomaly values attaining a peak of $104.1 \mathrm{mGal}$ was observed toward the NW section of the study area.

The residual field produced from more localised sources with short wavelengths, which usually are found at shallow depths was obtained by separation of the regional \& residual fields in the Bouguer data by employing the Upward continuation method \& Analytical method by least squares.

The upward continuation method is similar to low-pass filtering for it is used to remove high frequency contents from data. Upward continuation was carried out by using the program Fourpot, version 1.3 by Markku Pirttijärvi [18]. In order to carry out upward continuation on gravity data, the maximum height, $\mathrm{h}_{0}$, 


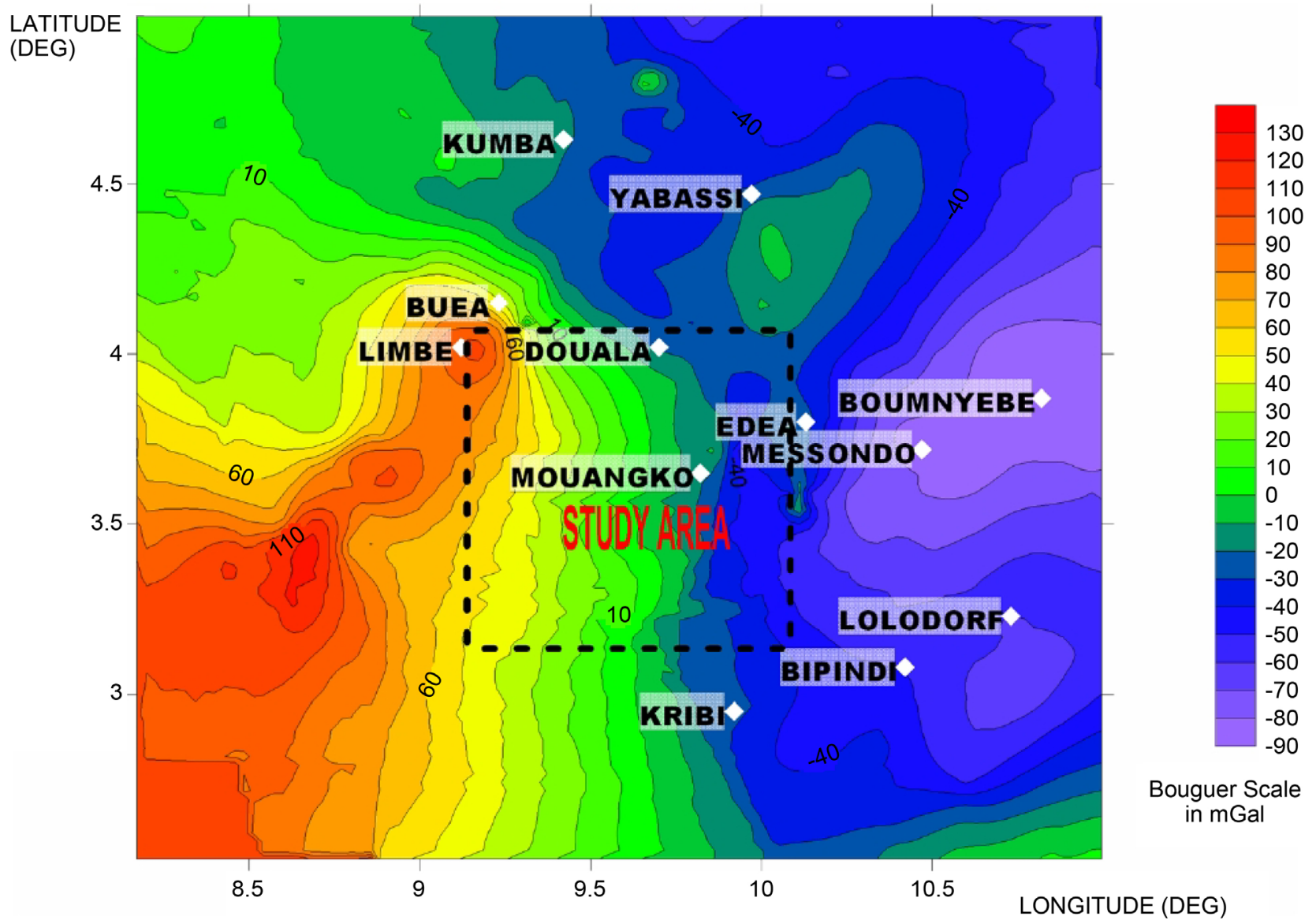

Figure 2. Bouguer anomaly map with study area indicated by black rectangle.

to be used has to be determined. This height is known as the optimum upward continuation height. This optimum height was obtained using the empirical method [19] to be equal to $30 \mathrm{~km}$.

The analytical method by least squares practically likens a regional field of order $\mathrm{n}$ to a polynomial of degree $\mathrm{n}$. Regional fields of different orders are therefore generated and the one that best fits the data is retained. In this study, correlation between regional fields that were generated for polynomial orders from $\mathrm{n}=$ 1 to $\mathrm{n}=10$ and the regional field obtained at the optimum continued height of $30 \mathrm{~km}$ was carried out in order to determine the highest correlation factor. The maximum correlation factor of 0.99 was obtained for a polynomial order of $n=$ 4.

The residual field thus obtained under these conditions was interpolated using the Kriging method to yield a $100 \times 100$ square grid with longitude and latitude spacings of 0.0285 and 0.0250 plotted with a contour interval of $5 \mathrm{mGal}$ [8]. These residual fields are characterised by many ring-like positive gravity anomaly contour lines in the study region.

Gradients were analysed for this residual field using the Multi-Scale Horizontal Derivative of the Vertical Derivative (MSHDVD) method [20] which did not contain any emphasis of quasi-linear contacts or quasi-circular contacts thus ex- 
cluding the existence of fault lines across this region.

When spectral analysis for source-depth estimation was carried out using the program Fourpot version 1.3, the result obtained on the residual field at the upward continuation height of $30 \mathrm{~km}$ suggest that the depth of the potential field source is about $4.8 \mathrm{~km}$.

\subsection{Ideal Body Solution}

The ideal body theory which characterizes the extremal solution with the smallest possible maximum density was originally developed by Parker [21] [22]. This theory is of much assistance in the fundamental problem of non-uniqueness encountered in the interpretation of gravity anomaly data. This is even the case when the solution set is bounded by physical or geologic constraints.

The ideal body theory is based on the basic philosophy that when a data set admits an infinite solution set, as is the case with potential fields, like the gravity field, properties common to all solutions are sought and as such definite information about the unknown true solution is derived.

In the specific case of gravity data, the maximum absolute value of the density contrast of the source constituting bounds on the uniform norm was treated by Parker. There exists a unique solution with the smallest possible uniform bound when a data set and a region in which a source is confined are considered. For all possible sources in that region of confinement, this source is attributed the term "ideal body" and its norm is the greatest bound on the maximum absolute value of all sources fitting the data. Consequently, any solution (as well as true one) must somewhere reach or exceed this bound [8].

Because the analysis of gravity ideal-body is especially well suited for handling sparse data contaminated with noise, for finding useful, rigorous bounds on the infinite solution set, and for predicting accurately what data need to be collected in order to tighten those bounds, it is an excellent reconnaissance exploration tool [23].

The program, IDB2, developed by Huestis and Ander [24] was used to obtain the ideal body solution in this study. The ideal body solution was obtained along a $50.2 \mathrm{~km}$ WWS-EEN profile (QQ') (Figure 3) using the following six (6) sets of distance (in $\mathrm{km}$ ) and gravity anomaly (in $\mathrm{mGal}$ ) points: $(0.87,46.10),(7.26$, 56.02), (13.65, 66.00), (20.05, 75.05), (27.43, 88.83) \& $(41.52,55.82)$.

The initial run of the program such that the ideal body touches the bottom of the volume indicated that the greatest lower bound on the density contrast of the source is equal to $0.266 \mathrm{~g} / \mathrm{cm}^{3}$ (see Figure 4). Using this value, this method suggests through other runs \& analysis that the minimum thickness of the ideal body should be $5.1 \mathrm{~km}$ while the maximum depth to the top of the ideal body is estimated at $11.5 \mathrm{~km}$. This value \& the shape of the ideal body plot (Figure 4) are very useful as they will serve as constraints for modelling.

\subsection{5D Modelling}

2.5D modelling has been carried out on the residual field using the program 


\section{LATITUDE (KM)}

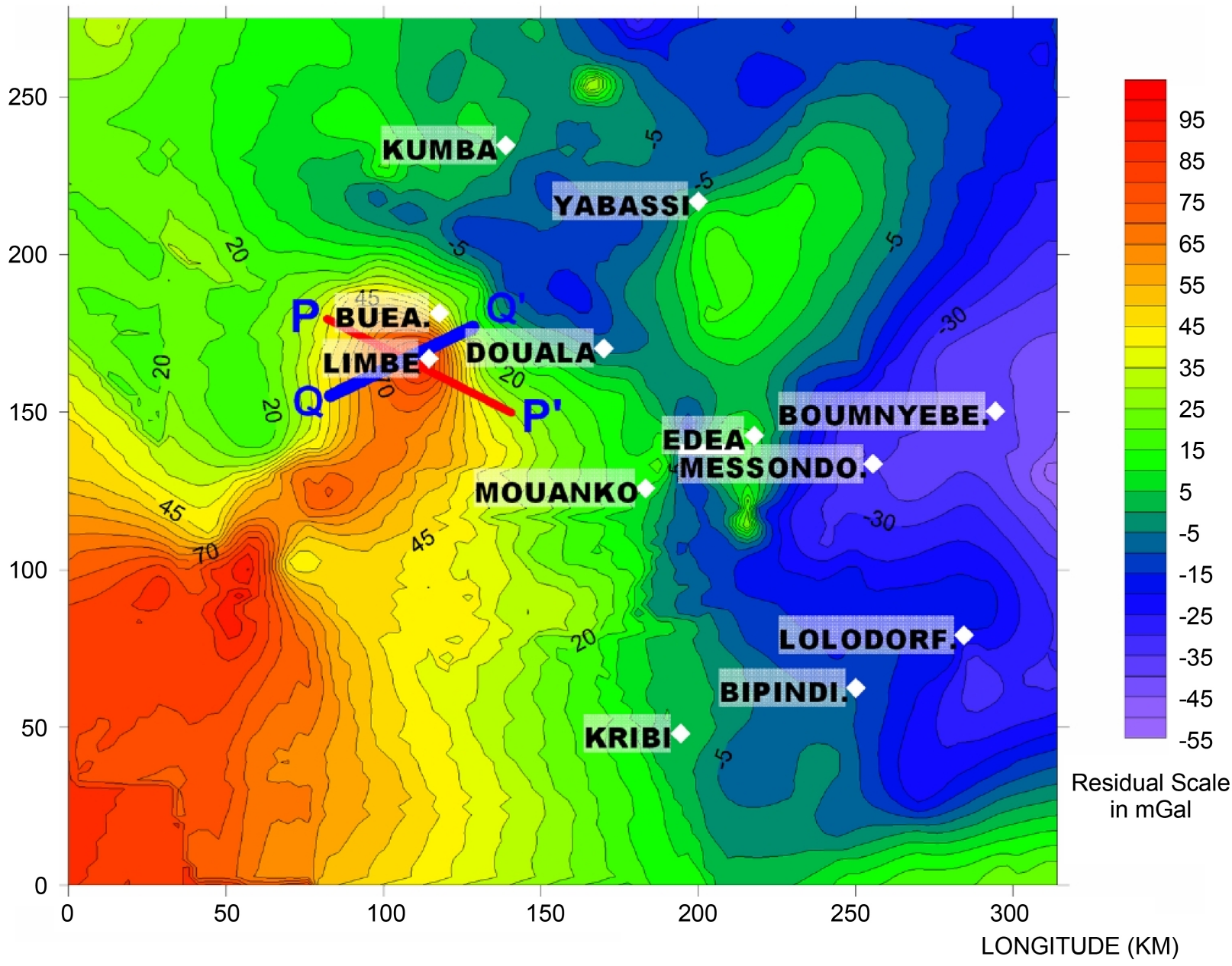

Cross Section of Profile NW-SE (PP')

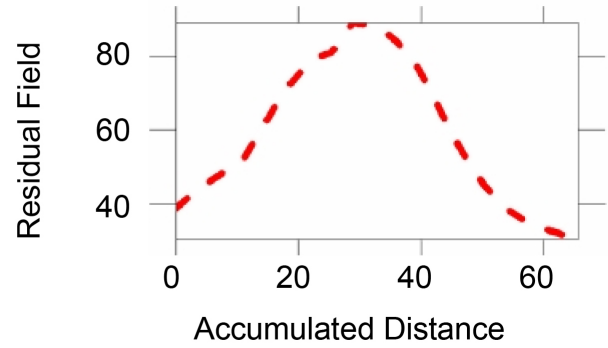

Cross Section of Profile WWS-EEN (QQ')

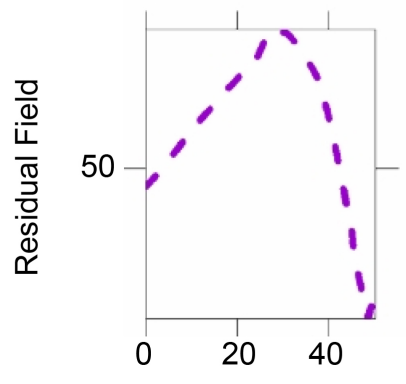

Accumulated Distance

Figure 3. Residual field plot in the study area showing WWS-EEN profile (QQ') and another profile (PP') used in previous studies [8].

GRAV2DC [25]. This program offers the possibility to interactively design a geological model in the form of a polygon whose gravity signature correlates with the observed anomalies. 2.5D modelling was carried out with this program using as constraints the value of the density contrast $\left(0.266 \mathrm{~g} / \mathrm{cm}^{3}\right)$ obtained from the ideal body solution; the result of spectral analysis and the result of 


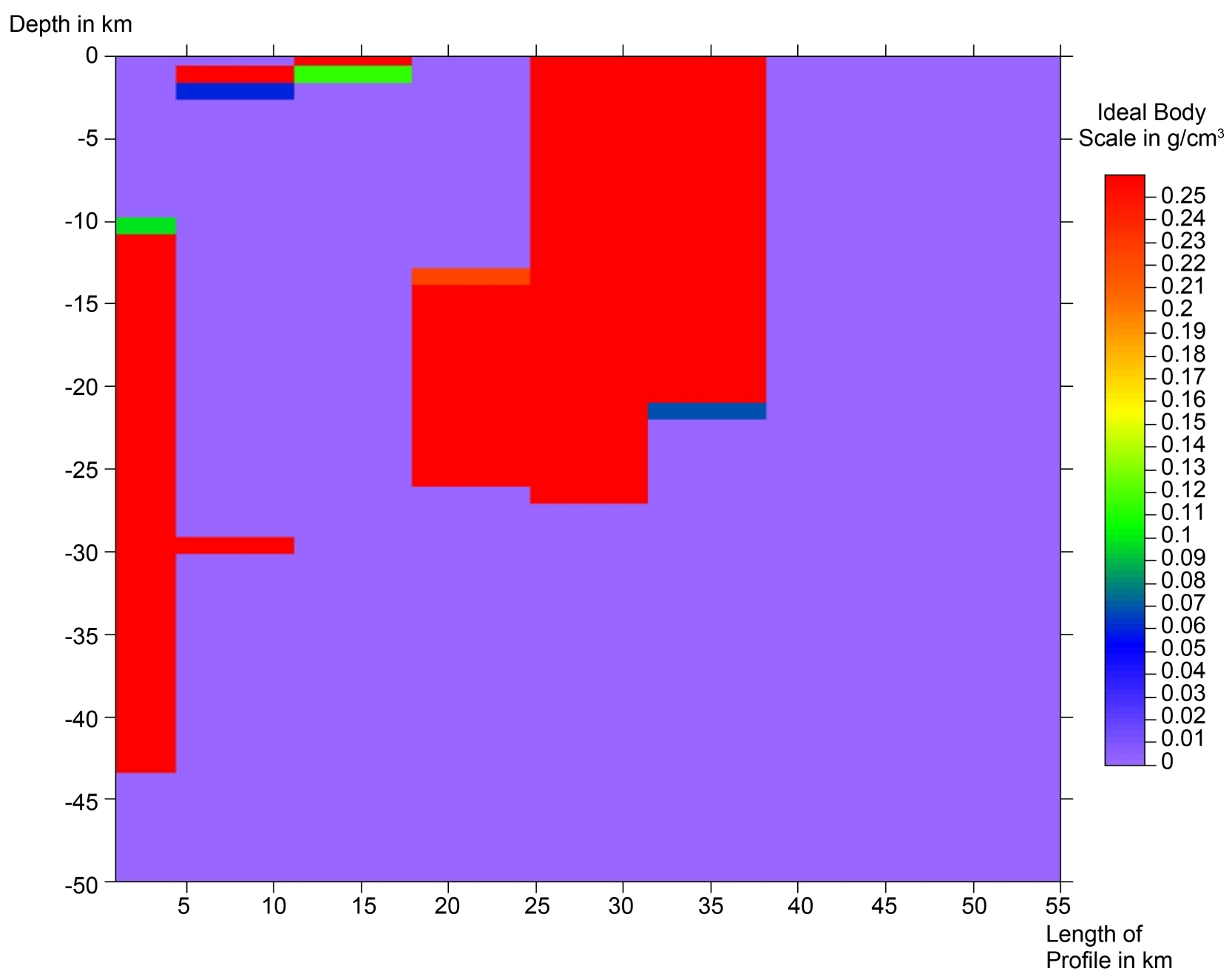

Figure 4. Ideal body plot when it is touching both the surface and bottom of the region of confinement. The greatest lower bound on the density contrast of the source is given to be equal to $0.26 \mathrm{~g} / \mathrm{cm}^{3}$. (Horizontal axis is distance in $\mathrm{km}$ along profile, vertical axis is depth in $\mathrm{km}$ with negative sign signifying depth increases downward, the scale takes values in $\mathrm{g} / \mathrm{cm}^{3}$ ).

multi-scale analysis of the maxima of gradients. The model obtained presented two major bodies both having a density contrast of $0.266 \mathrm{~g} / \mathrm{cm}^{3}$. The first body, step-like in shape, is located down to a depth of about $4.25 \mathrm{~km}$ with lateral extensions of $33 \mathrm{~km}$ in perpendicular directions to the profile QQ' and whose base is found at a depth of about $30.25 \mathrm{~km}$. The second body, found to the left of the first body and in form of a pillar, is down to a depth of about $10.77 \mathrm{~km}$ with lateral extensions of $30 \mathrm{~km}$ in perpendicular directions to the profile QQ' and has a base that appears to go deep beyond the crust-mantle boundary into the mantle (Figure 5).

Some very thin elongated blocks also appear in the model somewhere between the two major blocks: a first one with density contrast $0.266 \mathrm{~g} / \mathrm{cm}^{3}$ at a depth of about $3.6 \mathrm{~km}$ overlying two blocks of densities $0.059 \mathrm{~g} / \mathrm{cm}^{3} \& 0.114 \mathrm{~g} / \mathrm{cm}^{3}$ at depths of $5.63 \mathrm{~km} \& 4.73 \mathrm{~km}$ respectively; another of density contrast 0.266 $\mathrm{g} / \mathrm{cm}^{3}$ at a depth of $10.77 \mathrm{~km}$, and a last block (to the bottom left of the step-like block) of density $0.0685 \mathrm{~g} / \mathrm{cm}^{3}$ at a depth of $27.78 \mathrm{~km}$. 


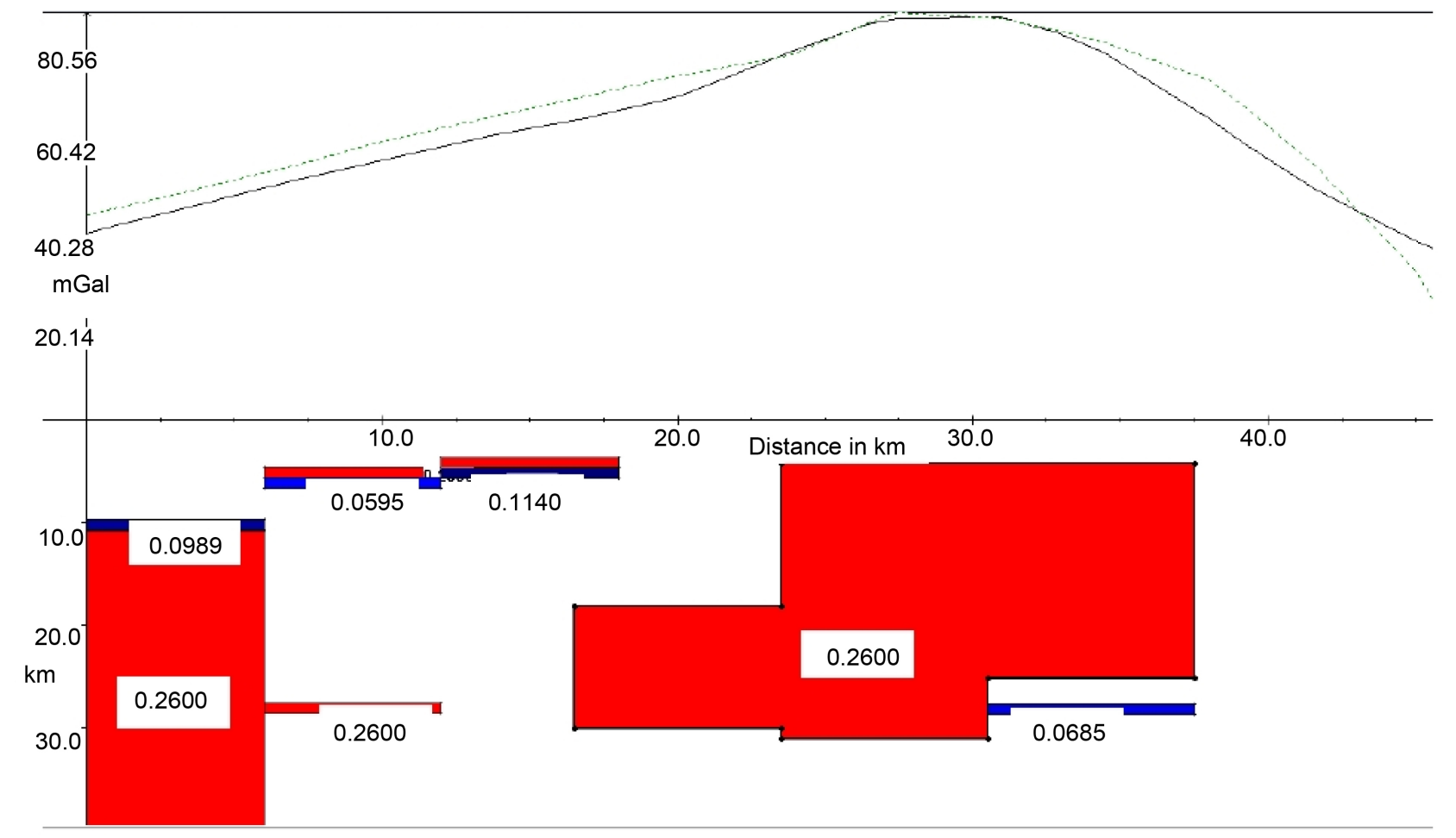

Figure 5. 2.5D model from the WWS-EEN Profile QQ' showing (in the lower section) two major blocks with density contrast = $0.26 \mathrm{~g} / \mathrm{cm}^{3}$ and other minor blocks (in the upper section, asterisks represent observed field while smooth line represents calculated field).

\section{Discussions}

The 2.5D model derived from the high gravity values found in the region of study as contained on the bouguer anomaly and the residual anomaly maps (Figure 2 and Figure 3) showed a considerable good match between the observed field and the calculated field (Figure 5).

Of the two major bodies present on this model, the step-like shaped block with density contrast of $0.266 \mathrm{~g} / \mathrm{cm}^{3}$ is very probably an intrusive body whose top lies at a depth of about $4.25 \mathrm{~km}$ which is approximately equal to the value of $4.8 \mathrm{~km}$ suggested by spectral analysis and considerably lesser than the maximum value of $11.5 \mathrm{~km}$ suggested by the ideal body solution. The body also has an average thickness of about $26 \mathrm{~km}$ (with its base lying at about $30.25 \mathrm{~km}$ ) which is in agreement with the suggestion by the ideal body solution that the minimum thickness of the body is $5.1 \mathrm{~km}$. This intrusive body with density contrast of $0.266 \mathrm{~g} / \mathrm{cm}^{3}$ which in its alignment is not completely vertical, but elongates and varies in steps horizontally will have a density of about $2.77 \mathrm{~g} / \mathrm{cm}^{3}$ considering the sedimentary background with average density of $2.5 \mathrm{~g} / \mathrm{cm}^{3}$ [25]. This implies that the intrusive body is of igneous origin. This totally agrees with the results of Ndikum et al. 2014 [8] which located an igneous intrusive body with similar characteristics along a NW-SE profile. Along the NW-SE profile, the body was found to have a thickness of about $26.9 \mathrm{~km}$ with its base at a depth of about 32.8 and its top at depth of about $5.9 \mathrm{~km}$.

Concerning the body with the shape of a pillar and having a density contrast 
of $0.266 \mathrm{~g} / \mathrm{cm}^{3}$, a similar analysis will suggest a density of about $2.77 \mathrm{~g} / \mathrm{cm}^{3}$. This body, along the QQ' profile, had an estimated length of $6 \mathrm{~km}$ moving from $\left(9^{\circ} 45.6^{\prime} \mathrm{E}, 4^{\circ} 57.2^{\prime} \mathrm{N}\right)$ to $\left(9^{\circ} 48.5^{\prime} \mathrm{E}, 4^{\circ} 58.6^{\prime} \mathrm{N}\right)$ at a depth of about $10.77 \mathrm{~km}$. This is in great agreement with the results of the study of Koumetio et al. [7] which identified a pillar of upper mantle formation with depth of about $14 \mathrm{~km}$. This pillar according to this result was located approximately between longitudes $9^{\circ} 46^{\prime} \mathrm{E}$ to $9^{\circ} 56^{\prime} \mathrm{E}$ and had its basement merges with the limit between mantle and crust of the Congo Craton. This surely explains why the pillar shaped body in this work has a base which goes beyond the crust-mantle boundary.

Furthermore, the many ring-like positive gravity anomaly contour lines seen in the study area on the Bouguer anomaly map (Figure 2) do agree with the results of Roussel and Lecorche [26] and Koumetio et al. [7] whose similarities suggested a more extensive movement that would have affected the whole of West African coast.

\section{Conclusion}

Bouguer anomaly fields have been extracted from a set of 116 gravity data points located between latitudes $3^{\circ} 03^{\prime} \mathrm{N}$ and $4^{\circ} 06^{\prime} \mathrm{N}$ and longitudes $9^{\circ} 00^{\prime} \mathrm{E}$ and $10^{\circ} 00^{\prime} \mathrm{E}$. These Bouguer fields were then processed at an upward continuation height of $30 \mathrm{~km}$ to obtain Residual fields which were characterised by high positive values. $2.5 \mathrm{D}$ modelling was carried out on the residual fields along a $50.2 \mathrm{~km}$ WWSEEN profile using as constraints the results from spectral analysis, the multiscale analysis of the maxima of gradients, and the inverse method of the ideal body solution. This model suggested the existence of two major blocks with density contrast of $0.266 \mathrm{~g} / \mathrm{cm}^{3}$ below this area of study. The first block was shown to be probably an intrusive igneous body with a density of about $2.77 \mathrm{~g} / \mathrm{cm}^{3}$ and it has an average thickness of about $26 \mathrm{~km}$ with its top and base lying at depths of about $4.25 \mathrm{~km}$ and $30.25 \mathrm{~km}$ respectively. The second block located at a depth of about $10.77 \mathrm{~km}$ was seen to be most likely a pillar of igneous material with a density of about $2.77 \mathrm{~g} / \mathrm{cm}^{3}$ whose base goes deep down beyond the crust-mantle boundary. The results obtained in this study also support the fact that there are similarities between the Douala sedimentary sub-basin and the coastal sedimentary basin of Mauritania-Senegal and so foster the suggestions of a more extensive movement that would have affected the whole of the West African coast.

\section{References}

[1] Brownfield, M.E. and Charpentier, R.R. (2006) Geology and Total Petroleum Systems of the West-Central Coastal Province (7203), West Africa. U.S. Geological Survey Bulletin 2207-B. https://pubs.usgs.gov/bul/2207/B/pdf/b2207b_508.pdf

[2] Tokam, K.A.P., Tabod, C.T., Nyblade, A.A., Julia, J., Wiens, D.A. and Pasyanos, M. (2010) Structure of the Crust beneath Cameroon, West Africa, from the Join Inversion of Rayleigh Wave Group Velocities and Receiver Functions. Geophysical Journal International, 183, 1061-1076. https://doi.org/10.1111/j.1365-246X.2010.04776.x

[3] Ndikum, E.N., Tabod, C.T. and Tokam, A.-P.K. (2014) Frequency Time Analysis (FTAN) and Moment Tensor Inversion Solutions from Short Period Surface Waves 
in Cameroon (Central Africa). Open Journal of Geology, 4, 33-43. https://doi.org/10.4236/ojg.2014.42004

[4] Ndikum, E.N., Tabod, C.T., Tokam, A.-P.K. and Essimbi, B.Z. (2014) Fault-Plane Solution of the Earthquake of 19 March 2005 in Monatele (Cameroon). Open Journal of Geology, 4, 289-293. https://doi.org/10.4236/ojg.2014.46021

[5] Njike, P.R.N. (1984) Contribution à l'étude Géologique Stratigraphique et Structurale de la Bordure du Basin Atlantique du Cameroun. Thèse de Doctorat $3^{\mathrm{e}}$ Cycle, Université de Yaoundé I, Faculté des Sciences, Cameroun.

[6] Legeley-Padovani, A., Poudjom-Djomani, Y.H., Boukeke, D-B., Nnange, J.M., Ateba-Bekoa, Albouy, Y. and Fairhead, J.D. (1996) Levés Gravimétriques de Reconnaissance du Cameroun. ORSTOM, Paris.

[7] Koumetio, F., Tabod, C.T. and Manguelle-Dicoum, E. (2009) Evidence for Upper Mantle Intrusion in the West African Coastal Sedimentary Basins from Gravity Data: The Case of the Southern Part of the Douala Basin, Cameroon. Global Journal of Geological Sciences, 7, 181-187.

[8] Ndikum, E.N., Tabod, C.T., Essimbi, B.Z., Koumetio, F. and Noutchogwe, C.T. (2014) Gravity Model for an Anomalous Body Located in the NW Protion of the Douala Sedimentary Sub-Basin, Cameroon (Central Africa). Open Journal of Geology, 4, 524-541. https://doi.org/10.4236/ojg.2014.410039

[9] Kenfack, P.L., Ngaha, P.R.N., Ekodeck, G.E. and Ngueutchoua, G. (2012) Mineralogic Characterization and Petroleum Potential of Clays (Shales) of the N'Kapa Formation (Paleocene-Eocene) in the Douala Sedimentary Sub-basin (South-West Cameroon). International Journal of Geosciences, 3, 696-709. https://doi.org/10.4236/ijg.2012.34070

[10] Kenfack, P.L., Njike, P.R.N., Ekodeck, G.E. and Ngueutchoua, G. (2012) Fossils Dinoflagellates from the Northern Border of the Douala Sedimentary Sub-Basin (South-West Cameroon): Age Assessment and Paleoecological Interpretations. Geosciences, 2, 117-124.

[11] Reyre, D. (1966) Bassins Sédimentaires du Littoral Africain. Symposium: Littoral Atlantique (New Delhi). Association des services Géologique Africains.

[12] Hoffman, P. (1971) Aulacogènes and Orthogeosynclines in the Lower Proterozoic of the Northwestern Canadian Shield. Geological Society of America, Abstracts With Programs, 3.

[13] Nguene, F.R., Tamfu, S., Loule, J.P. and Ngassa, C. (1992) Paleoenvironnements of the Douala and Kribi/Campo Subbasins in Cameroon, West African. Géologie Africaine: Colloque de Géologie Africaine, Libreville, Recueil des Communications, 6-8 May 1991, 129-139.

[14] Regnoult, J.M. (1986) Synthèse gélogique du Cameroun. D.M.G, Yaoundé, X p.118.

[15] SNH/UD (2005) Stratigraphie séquentielle et Tectonique des dépôts mésozoïques syn-rifts du Bassin de Kribi/Campo. Rapport non publié, X p. 134.

[16] Ngon, G.F.N., Etame, J., Ntamak-Nida, M.J., Mbog, M.B., Mpondo, A.M.M., Martine, G., Yongue-Fouateu, R. and Bilong, P. (2012) Geological Study of Sedimentary Clayey Materials of the Bomkoul Area in the Douala Region (Douala Sub-Basin, Cameroon) for the Ceramic Industry. Comptes Rendus Geoscience, 344, 366-376. https://doi.org/10.1016/j.crte.2012.05.004

[17] Selley, R.C. (1997) African Basins (Sedimentary Basins of the World). Volume 3, Elsevier Science B.V., Amsterdam.

[18] Pirttijärvi, M. (2009) FOURPOT, University of Oulu, Department of Physics, Geophysics. 
https://wiki.oulu.fi/download/attachments/20678098/Fourpot_1.3b.zip?version=1\& modificationDate $=1470047813000 \&$ api $=\mathrm{v} 2$

[19] Zeng, H., Xu, D. and Tan, H. (2007) A Model Study for Estimating Optimum upward Continuation Height for Gravity Separation with Application to a Bouguer Gravity Anomaly over a Mineral Deposit, Jilin Province, Northeast China. Geophysics, 72, 145-150. https://doi.org/10.1190/1.2719497

[20] Koumetio, F., Njomo, D., Tabod, C.T., Noutchogwe T.C. and Manguelle-Dicoum, E. (2012) Structural Interpretation of Gravity Anomalies from the Kribi-Edea Zone, South Cameroon: A Case Study. Journal of Geophysics and Engineering, 9, 664-673. https://doi.org/10.1088/1742-2132/9/6/664

[21] Parker, R.L. (1974) Best Bounds on Density and Depth from Gravity Data. Geophysics, 39, 644-649. https://doi.org/10.1190/1.1440454

[22] Parker, R.L. (1975) The Theory of Ideal Bodies for Gravity Interpretation. Geophysical Journal International, 42. 315-334. https://doi.org/10.1111/j.1365-246X.1975.tb05864.x

[23] Ander, M.E. and Huestis, S.P. (1987) Gravity Ideal Bodies. Geophysics, 52, 1265 1278. https://doi.org/10.1190/1.1442387

[24] Huestis, S.P. and Ander, M.E. (1983) IDB2-A FORTRAN Program for Computing Extremal Bounds in Gravity Data Interpretation. Geophysics, 48, 999-1010. https://doi.org/10.1190/1.1441525

[25] Cooper, G.R.J. (1998) GRAV2DC for Windows User's Manual (version 2.05). University of the Witwatersrand, Geophysics Department, Johannesburg.

[26] Roussel, J. and Lecorce, J.P. (1983) Regional Gravity Trends Associated with the Mauritanides Orogen (West Africa). Reidel Publishing Company, 116, 63-71. https://doi.org/10.1007/978-94-009-7239-1_8

\section{Submit or recommend next manuscript to SCIRP and we will provide best} service for you:

Accepting pre-submission inquiries through Email, Facebook, LinkedIn, Twitter, etc. A wide selection of journals (inclusive of 9 subjects, more than 200 journals)

Providing 24-hour high-quality service

User-friendly online submission system

Fair and swift peer-review system

Efficient typesetting and proofreading procedure

Display of the result of downloads and visits, as well as the number of cited articles

Maximum dissemination of your research work

Submit your manuscript at: http://papersubmission.scirp.org/

Or contact gep@scirp.org 